\title{
Pengaruh Metode Gentle Birth Terhadap Tingkat Nyeri Dan Durasi Kala I Persalinan Pada Ibu Primipara
}

\author{
Rezah Andriani ${ }^{1,}$ Selvy Apriani ${ }^{2}$ \\ ${ }^{1,2}$ Program Studi D III Kebidanan, STIKes Muhammadiyah Palembang \\ ahsanalmaisan@gmail.com, selvy.apriani.26@gmail.com
}

\section{KATA KUNCI: Gentle \\ birth, prental yoga, hypnobirthing, nyeri persalinan, durasi persalinan}

\begin{abstract}
ABSTRAK
World Health Organization memperkirakan setiap menit perempuan di dunia meninggal karena komplikasi terkait dengan kehamilan dan persalinan. 1.400 perempuan meninggal setiap harinya atau 500.000 perempuan meninggal setiap tahun karena komplikasi kehamilan dan persalinan. Komplikasi dalam persalinan dapat meningkatkan mortalitas dan morbiditas baik pada ibu maupun bayi. Komplikasi persalinan yang banyak dilaporkan adalah persalinan lama $(41 \%)$ Persalinan yang berlangsung lama dan rasa sakit selama proses persalinan merupakan penyebab dari trauma persalinan serta dapat meningkatnya persalinan melalui sectio caesarea. Maraknya tren operasi sesar dan intervensi medis lainnya yang tidak perlu, maka lahirlah semacam kesadaran untuk kembali pada konsep persalinan yang alami dan memperhatikan semua aspek tubuh manusia secara holistik (gentle birth). "Gentle birth" merupakan persalinan yang tenang, lembut, santun, dan memanfaatkan semua unsur alami dalam tubuh seorang manusia (body, mind, and soul). Saat ini berkembang metode-metode alternatif dalam proses persalinan yang berkonsep gentle birth, diantaranya prental yoga dan relaksasi hypnobirthing. Penelitian ini merupakan penelitian quasi eksperimen dengan post test control group design. Pengambilan sampel dilakukan secara consecutive sampling dengan jumlah sampel 60 orang. Penelitian dilakukan selama 6 bulan dari bulan April-September di 2 bidan praktik mandiri kota Palembang. Tujuan penelitian untuk menganalisis pengaruh metode gentle birth terhadap tingkat nyeri dan durasi kala I persalinan pada ibu primipara. Hasil penelitian terdapat perbedaan yang bermakna pada tingkat nyeri maupun durasi kala I persalinan. Hasil penelitian ini diharapkan memberikan kontribusi terhadap ilmu kebidanan sebagai salah satu upaya untuk memberikan asuhan kebidanan persalinan secara holistik (gentle birth) untuk mengurangi nyeri persalinan serta memperpendek durasi persalinan.
\end{abstract}

\section{ABSRACT}

According to World Health Organization, it is estimated that one woman dies in every minute, 1,400 in every day, or 500,000 in every year from pregnancy- and delivery-related complications. A large number of delivery-related complications reported in SDKI in 2017 are long delivery (41\%). Both long delivery and pain that distress the mother during a delivery process is the reason for delivery trauma and increases in delivery by sectio caesarea operation. Increasing trends in caesarea operation and other unnecessary medical interventions, there reemerges an awareness to back to a natural delivery concept that considers the whole aspects of human body holistically (called gentle birth). "Gentle birth" is a serene, smooth, gentle delivery and utilizes all natural elements in human (body, mind, and soul). Currently, some alternative methods of delivery process with a gentle birth concept are developing, such as prental yoga and hypnobirthing relaxation. The research is a quasi-experimental research with a post test control group design. Sampling was performed by a consecutive sampling with a sample of 60 people. The study was conducted for 6 months from April to September in 2 midwives practicing independently in the city of Palembang.The objective of the present research is to analyze the effect of gentle birth method on the pain level and phase-I duration of delivery in primipara mother. The research result revealed that there was some significant average difference in the pain level and phase-I duration of delivery. Expectantly, the research result contributes to midwifery science as an attempt to deliver a holistic delivery midwifery care (gentle birth) so as to relieve delivery-related pain and to shorten delivery duration.

\section{PENDAHULUAN}

Kehamilan dan persalinan adalah kejadian penting bagi kehidupan seorang perempuan dan keluarganya. Kehamilan dan persalinan bisa menjadi harapan, antisipasi, tetapi juga bisa menjadi sesuatu yang menakutkan dan bahkan bisa menyebabkan terjadinya kematian. Komplikasi kehamilan 
dan persalinan sering berakhir dan menyebabkan terjadinya kesakitan dan kematian pada wanita di Negara berkembang. Beberapa jenis komplikasi kehamilan akan dialami oleh setidaknya $40 \%$ wanita hamil selama kehamilannya dan penanganan kegawatdaruratan obstetri sekitar $15 \%$ sangat dibutuhkan segera karena komplikasi ini akan berpotensi mengancam jiwa. [1]

Penelitian di Ethiopia pusat menemukan hanya $38,6 \%$ dari ibu hamil yang memahami gejala awal dari komplikasi pada masa kehamilan artinya pengetahuan ibu tentang gejala awal dari komplikasi kehamilan masih rendah. Responden yang tidak mengetahui tentang tanda-tanda bahaya kehamilan ini mayoritas $92 \quad(60,1 \%)$ mengatakan tidak pernah mendapatkan informasi artinya dari tenaga kesehatan dan 61 $(39,9 \%)$ mengatakan jauh dari tempat pelayanan kesehatan. [2]

Angka Kematian Ibu (AKI) di Indonesia saat ini masih tergolong tinggi dibandingkan dengan Negara di kawasan Asia Tenggara. Berdasarkan data SUPAS 2015, AKI di Indonesia sebesar 305/100.000 kelahiran hidup pada tahun 2015.

Millennium Development Goals (MDGs) menargetkan AKI turun pada tahun 2015 menjadi 102/100.000 KH, akan tetapi pada kenyataannya AKI masih tinggi. Sebagai upaya kelanjutan dari MDGs, Sustainable Development Goals (SDGs) menargetkan AKI secara global kurang dari 70/100.000 KH pada tahun 2030. [4]

Kematian ibu secara umum dipengaruhi oleh beberapa faktor penyebab, antara lain yaitu penyebab langsung (direct) dan penyebab tidak langsung (indirect). Komplikasi pada masa kehamilan, melahirkan dan masa post partum, seperti perdarahan, pre eklamsi/eklamsi, infeksi, persalinan macet dan abortus merupakan penyebab langsung (direct) kematian ibu yang menyumbang angka sebesar $75 \%$ angka kematian ibu. Sedangkan faktor "Empat Terlalu" yaitu terlalu muda, terlalu tua, terlalu sering melahirkan dan terlalu dekat jarak jarak kelahiran dan "Tiga Terlambat", yaitu terlambat mengenali tanda bahaya dan mengambil keputusan, terlambat mencapai fasilitas kesehatan, terlambat mendapat penanganan di fasilitas kesehatan menjadi penyebab inderect dari kematian maternal di Indonesia. [5]

Hasil penelitian oleh El-Nagar.,et,al tahun 2017 tentang pengetahuan dan praktik ibu hamil terhadap tanda bahaya komplikasi kebidanan menemukan bahwa sekitar dua pertiga $(64,5 \%)$ dari ibu hamil menunjukkan pengetahuan yang kurang mengenai tandatanda bahaya komplikasi kehamilan, sepertiga $(34,0 \%)$ ibu hamil memiliki pengetahuan cukup, dan hanya $1,5 \%$ dari ibu hamil yang mempunyai pengetahuan baik. Praktik yang dilakukan ibu hamil saat mengalami tandatanda bahaya kehamilan, mayoritas ibu hamil $(95,7 \%)$ pergi ke dokter, sementara antisipasi apabila terjadi tanda-tanda bahaya persalinan dan masa nifas, masing-masing $42,5 \%$ dan $36,2 \%$ akan berkonsultasi dengan dokter dan pergi ke rumah sakit.[1]

Penelitian ini ingin mengetahui hubungan antara pengetahuan ibu hamil tentang tanda-tanda bahaya kehamilan dengan praktek saat terjadi komplikasi kehamilan.

\section{TINJAUAN PUSTAKA}

Pengetahuan seorang ibu mengenai tanda-tanda bahaya kehamilan merupakan salah satu cara yang dianggap jitu karena memiliki tujuan untuk meningkatkan pengetahuan ibu hamil melalui pemanfaatan pelayanan tenaga kesehatan yang terampil pada kasus kegawatdaruratan obstetrik. Salah satu strategi untuk menurunkan Angka Kematian Ibu (AKI) yaitu dengan meningkatkan pengetahuan ibu hamil tentang tanda-tanda bahaya kehamilan, persiapan persalinan dan kesiapan menghadapi komplikasi. Hasil penelitian di Uganda hanya $19 \%$ ibu hamil yang mengetahui tentang tanda-tanda bahaya kehamilan.[6]

Tingkat pengetahuan wanita mengenai tanda-tanda bahaya kehamilan dipengaruhi oleh beberapa faktor. Beberapa penelitian menunjukkan karakteristik sosio-demografi 
seperti umur, tingkat pendidikan dan status pekerjaan serta karakteristik kehamilan seperti jumlah kehamilan, jumlah persalinan dan jumlah kunjungan antenatal berkontribusi terhadap pengetahuan ibu hamil. Setiap kehamilan berisiko bagi seorang perempuan. Sebagai upaya dalam meningkatkan kesehatan maternal dan neonatal diperlukan parameter dan salah satunya adalah pengetahuan ibu hamil tentang tanda-tanda bahaya kehamilan. Hasil penelitian di Malaysia 23,6\% ibu hamil mempunyai tingkat pengetahuan yang rendah tentang tanda-tanda bahaya kehamilan. [7]

Penelitian Hailu.,et,al tahun 2010 menemukan hasil yang sama bahwa pada kenyataannya banyak wanita hamil yang tidak mengetahui bahwa tanda-tanda bahaya kehamilan merupakan masalah yang serius yang dapat menyebabkan komplikasi dalam kehamilan dan persalinan. Apabila ibu hamil dan keluarganya mampu mengenali tandatanda bahaya dan komplikasi kehamilan kemungkinan bisa mengurangi angka keterlambatan dalam mengambil keputusan ke pelayanan kesehatan. Pada penelitian ini juga ditemukan kurang dari setengah wanita hamil yang mampu menyebutkan dua dari tandatanda bahaya kehamilan dan persalinan. [8]

Strategi focus yang bertujuan untuk menurunkan kematian maternal dan neonatal salah satunya yaitu dengan melakukan pemberdayaan perempuan, keluarga dan support system masyarakat untuk memahami faktor resiko tanda-tanda bahaya yang berhubungan dengan masa kehamilan dan mencari pertologan yang tepat apabila mengalami tanda bahaya maupun komplikasi. [3]

Komplikasi kehamilan dapat membahayakan kehidupan ibu dan janin, akan tetapi tidak semua wanita yang mengalami komplikasi kehamilan atau kondisi yang abnormal mempunyai pengetahuan yang cukup tentang tanda-tanda bahaya dan komplikasi kehamilan. Tanda-tanda bahaya kehamilan bukan hanya berhubungan dengan komplikasi obstetrik, tetapi gejala-gejala tersebut juga dapat dikenali dari gejala non klinik lainnya. Tanda-tanda bahaya komplikasi kehamilan yang umum terjadi pada ibu hamil meliputi perdarahan pervaginam, kejangkejang, sakit kepala hebat dengan pandangan mata kabur, demam dan tidak bias bangun dari tempat tidur, nyeri perut hebat dan nafas cepat atau susah bernafas. [8]

Perdarahan yang keluar dari jalan lahir, nyeri perut yang adekuat, melemahnya gerakan janin, bengkak/oedema pada muka, tangan, kaki; penglihatan mata kabur, nyeri kepala yang tidak tertahankan, demam, hyperemesis gravidarum, keluar cairan ketuban secara spontan tiba-tiba dari jalan lahir merupakan tanda-tanda bahaya yang dapat dialami oleh perempuan pada masa kehamilan. Selain itu juga faktor resiko yang dapat menyebabkan timbul nyata dan bahaya kehamilan antara lain, umur ibu hamil $<20$ tahun, umur ibu hamil > 35 tahun, jumlah anak 4 orang atau lebih, jarak dengan anak sebelumnya $<2$ tahun, tinggi badan $<145 \mathrm{~cm}$, lingkar lengan atas $<23,5 \mathrm{~cm}[9]$

\section{METODE}

Desain penelitian yang digunakan dalam penelitian ini adalah penelitian analitik dengan desain Cross Sectional. Penelitian ini bertujuan mengetahui hubungan antara pengetahuan ibu hamil tentang tanda-tanda bahaya kehamilan dengan praktek saat terjadi komplikasi kehamilan. Penelitian dilakukan dari bulan Maret sampai Oktober 2020. Data yang digunakan dalam penelitian ini merupakan data primer. Metode pengambilan data menggunakan menggunakan kuesioner yang dikembangkan menggunakan Google Form. Populasi penelitian adalah seluruh ibu hamil yang terjaring di Bidan Praktek Mandiri (BPM) di wilayah Jakarta dan sekitarnya. Sampel penelitian berjumlah 111 responden yang memenuhi kriteria inklusi dan eksklusi. Metode pengambilan sampel menggunakan Purposive Sampling. Proses analisa data menggunakan analisa Univariat dan analisa Bivariate, analisa Bivariate menggunakan uji Chi square. 


\section{HASIL DAN PEMBAHASAN}

Karakteristik responden penelitian berdasarkan riwayat obstetrik dalam penelitianini terdiri dari jumlah kehamilan (gravida), usia kehamilan pada kunjungan awal ANC, Usia Kehamilan saat ini, jumlah kunjungan ANC dan Riwayat Komplikasi Obstetrik, seperti pada tabel 1.

Tabel 1

Karakteristik Responden Berdasarkan

Riwayat Obstetrik

\begin{tabular}{|c|c|c|}
\hline Variabel & $\begin{array}{r}\text { Frekuensi } \\
(\mathbf{N})\end{array}$ & Persentase $(\%)$ \\
\hline \multicolumn{3}{|l|}{ Gravida } \\
\hline 1 kali & 53 & 47,7 \\
\hline 2-4 kali & 45 & 40,5 \\
\hline$>4$ kali & 13 & 11.8 \\
\hline \multicolumn{3}{|c|}{$\begin{array}{l}\text { Usia Kehamilan Pada Kunjungan awal } \\
\text { ANC }\end{array}$} \\
\hline$>8$ minggu & 23 & 20,7 \\
\hline 4-8 minggu & 88 & 79,3 \\
\hline \multicolumn{3}{|l|}{ Usia Kehamilan Saat ini } \\
\hline Trimester I & 34 & 30,6 \\
\hline Trimester II & 49 & 44,1 \\
\hline Trimester III & 28 & 25,3 \\
\hline \multicolumn{3}{|l|}{ Jumlah kunjungan ANC } \\
\hline$<4$ & 61 & 55 \\
\hline$>4$ & 50 & 45 \\
\hline \multicolumn{3}{|l|}{ Riwayat Komplikasi Obtsetrik } \\
\hline Ada & 11 & 9,9 \\
\hline Tidak Ada & 100 & 90,1 \\
\hline
\end{tabular}

Berdasarkan tabel. 1 Karakteristik responden berdasarkan riwayat obstetrik, berdasarkan jumlah kehamilan (Gravida), responden paling banyak dengan Gravida 1 kali yaitu 53 responden (47.7\%), Gravida 2-4 kali 45 responden $(40,5 \%)$ dan Gravida $>4$ kali sebanyak 13 responden (11,8\%). Berdasarkan usia kehamilan pada kunjungan awal, responden yang pertama kali melakukan kunjungan kehamilan pada usia kehamilan 4-8 minggu sebanyak 88 responden $(79,3 \%)$, sisanya melakukan kunjungan pertama pada usia kehamilan $>8$ minggu yaitu 23 responden $(20,7 \%)$. Berdasarkan usia kehamilan saat dilakukan penelitian, Trimester I sebanyak 34 responden $(30,6 \%)$, trimester II sebanyak 49 responden $(44,1 \%)$ dan trimester III sebanyak
$28(25,3 \%)$. Berdasarkan komplikasi obstetrik ada 11 responden $(9,9 \%)$ ada riwayat komplikasi obstetrik sebelumnya dansebanyak 100 responden $(90,1 \%)$ tidak ada riwayat komplikasi obstetrik.

Tingkat pengetahuan wanita tentang tanda-tanda bahaya kehamilan dipengaruhi oleh beberapa faktor. Beberapa penelitian menunjukkan karakteristik sosio-demografi seperti umur, tingkat pendidikan dan status pekerjaan serta karakteristik kehamilan seperti jumlah kehamilan, jumlah persalinan dan jumlah kunjungan antenatal berkontribusi terhadap pengetahuan ibu hamil. Setiap kehamilan berisiko bagi seorang perempuan. Pengetahuan ibu hamil tentang tanda-tanda bahaya kehamilan merupakan parameter untuk 
meningkatkan kesehatan ibu dan anak.[1]

Kunjungan antenatal dapat mendeteksi dan menyelesaikan masalah selama kehamilan dan dapat meningkatkan kesehatan wanita selama kehamilan, dan dapat mendeteksi dini terjadinya komplikasi. [10]

Tabel 2

Tingkat Pengetahuan Responden Tentang Tanda-tanda Bahaya Kehamilan

\begin{tabular}{lcc}
\hline \multicolumn{1}{c}{ Variabel } & Frekuensi (N) & Persentase (\%) \\
\hline Pengetahuan Baik & 23 & 12,1 \\
Pengetahuan Cukup & 27 & 14,2 \\
Pengetahuan Kurang & 61 & 32,1 \\
\hline
\end{tabular}

Berdasarkan tabel. 2 gambaran pengetahuan responden tentang tanda-tanda bahaya kehamilan, responden dengan tingkat pengetahuan baik 23 responden $(12,1 \%)$, pengetahuan cukup 27 responden $(14,2 \%)$ dan responden dengan pengetahuan kurang sebesar 61 responden $(32,1 \%)$.

Berdasarkan penelitian di Ethiopia Pusat, hanya $38,6 \%$ dari ibu hamil yang mengetahui tentang tanda-tanda bahaya kehamilan dan hal ini tergolong sangat rendah. Responden yang tidak mengetahui tentang tanda-tanda bahaya kehamilan ini mayoritas $92(60,1 \%)$ mengatakan tidak pernah mendapatkan informasi dari tenaga kesehatan dan $61(39,9 \%)$ mengatakan jauh dari tempat pelayanan kesehatan. [2]

Konseling tentang tanda-tanda bahaya komplikasi kehamilan saat pemeriksaan Ante Natal Care (ANC) sangat penting sebab bisa meningkatkan kewaspadaan ibu hamil dalam deteksi dini pencegahan komplikasi kehamilan. [11]

Tabel 3

Distribusi Frekuensi Praktik Ibu Hamil Saat Mengalami Komplikasi Obstetrik

\begin{tabular}{|c|c|c|c|c|}
\hline \multicolumn{3}{|c|}{ Variabel } & Frekuensi (N) & Persentase (\%) \\
\hline $\begin{array}{l}\text { Pergi Ke Tenaga } \\
\text { kesehatan }\end{array}$ & 69 & 36,3 & & \\
\hline Istirahat & & & 25 & 13,2 \\
\hline Minum Obat & & & 10 & 5,3 \\
\hline $\begin{array}{l}\text { Tidak Melakukan } \\
\text { apapun }\end{array}$ & 7 & 3,7 & & \\
\hline
\end{tabular}

Berdasarkan tabel 3 distribusi frekuensi praktik ibu hamil ketika mengalami komplikasi obstetrik, 69 responden $(36,3 \%)$ pergi ketenaga kesehatan; 25 responden $(13,2 \%)$ istirahat; 10 responden $(5,3 \%)$ minum obat dan 7 responden $(3,7 \%)$ tidak melakukan apapun.

Setiap wanita hamil beserta pasangan dan keluarganya harus mempunyai kemampuan dan kepedulian dalam mengenali tanda-tanda bahaya dan melakukan deteksi dini komplikasi kegawat daruratan pada kehamilan sehingga bias terhindar dari bahaya kematian akibat kehamilan tersebut.[9]

Hasil penelitian di daerah Urban Tanzania menunjukkan 4 dari 384 Participants ibu hamil, 67 orang $(17,4 \%)$ pernah mengalamitanda-tanda bahaya pada kehamilan dan 61 orang $(91 \%)$ dari ibu hamil yang mengalami tanda-tanda bahaya kehamilan tersebut langsung datang kefasilitas kesehatan 
saat mengalami tanda-tanda bahaya kehamilan.[12]

Studi lain menunjukkan rendahnya kesadaran akan tanda-tanda bahaya dan kesiapsiagaan menghadapi komplikasi kelahiran disebabkan karena wanita tersebut kurang mendapatkan pendidikan kesehatan, sehingga hal ini menyebabkan ibu hamil tersebut terlambat mengambil keputusan. [13]

Tabel 4

Hubungan antara Pengetahuan dan Praktek Ibu Hamil Saat Mengalami Komplikasi Kehamilan

\begin{tabular}{|c|c|c|c|c|c|c|c|}
\hline \multirow[t]{2}{*}{ Pengetahuan } & \multicolumn{4}{|c|}{ Praktik } & \multicolumn{2}{|c|}{ Total } & \multirow[t]{2}{*}{ P-Value } \\
\hline & $\begin{array}{c}\text { Ke } \\
\text { dokter }\end{array}$ & Istirahat & $\begin{array}{c}\text { Minum } \\
\text { obat }\end{array}$ & $\begin{array}{c}\text { Tidak } \\
\text { melakukan } \\
\text { apapun }\end{array}$ & $\mathbf{N}$ & $\%$ & \\
\hline Baik & 16 & 6 & 0 & 1 & 23 & 20,7 & \multirow{4}{*}{0,091} \\
\hline Cukup & 14 & 7 & 3 & 3 & 27 & 24,3 & \\
\hline Kurang & 39 & 12 & 7 & 3 & 61 & 55 & \\
\hline Total & 69 & 25 & 10 & 7 & 111 & 100 & \\
\hline
\end{tabular}

Berdasarkan tabel 4 dapat diketahui bahwa responden yang berpengetahuan baik sebanyak 16 orang pergi ke tenaga kesehatan atau dokter saat mengalami komplikasi kehamilan. Responden yang berpengetahuan cukup sebanyak 14 orang pergi ke tenaga kesehatan atau dokter saat mengalami komplikasi kehamilan dan sebanyak 39 orang yang berpengetahuan kurang juga pergi ke tenaga kesehatan atau dokter saat mengalami komplikasi kehamilan. Berdasarkan hasil uji chi square didapati hasil $\mathrm{p}$ value 0,091 yang berarti tidak terdapat hubungan yang signifikan antara pengetahuan dan praktik saat mengalami komplikasi kehamilan.

Banyak faktor yang menjadi penentu praktik ibu hamil ketika mengalami komplikasi kehamilan, bukan hanya pengetahuan tetapi juga edukasi kesehatan. Edukasi kesehatan saat antenatal care menjadi komponen penting bagi ibu hamil untuk memutuskan kapan segera pergi ke tenaga kesehatan apabila ada komplikasi kehamilan. [14] Pada penelitian ini sebanyak 69 ibu hamil memilih untuk melakukan pemeriksaan ke dokter atau tenaga kesehatan ketika mengalami komplikasi hal ini bisa diperngaruhi salah satunya jumlah kehamilan seorang ibu. Pada penelitian ini terdapat 53 responden yang baru pertama kali hamil sehingga tingkat kecemasan atau kekhawatiran ketika menghadapi komplikasi kehamilan akan jauh lebih tinggi.

Salah satu penyebab tingginya angka kematian ibu (AKI) salah satunya yaitu program deteksi dini yang belum berjalan dengan baik, yang menyebabkan tingginya angka kematian ibu dan bayi. Hal ini salah satunya disebabkan karena permasalahan pada ibu hamil seperti rendahnya kualitas pengetahuan ibu tentang komplikasi kehamilan. [15]

\section{KESIMPULAN}

Pada penelitian ini tidak terdapat hubungan antara pengetahuan dan praktek ibu hamil saat mengalami komplikasi kehamilan. Saran perlu adanya kelas antenatal untuk semua wanita hamil yang membahas tentang tanda bahaya kehamilan dan praktek pencarian pertolongan saat terjadi tanda bahaya komplikasi. 


\section{DAFTAR PUSTAKA}

[1] El-Nagar, A. E., Ahmed, M. H., \& Belal, G. E.-S. Knowledge and Practices of Pregnant Women Regarding Danger Signs of Obstetric Complications. IOSR Journal of Nursing and Health Science , 30-41, 2017.

[2] Solomon, A. A., et.al. Knowledge About Danger Signs of Pregnancy and Assosiated Factors Among Pregnant Women in Debra Birhan Town, Central Ethiopia. Science Journal of Public Health , 269-273, 2015.

[3] Kementrian Kesehatan Republik Indonesia, Profil Kesehatan Indonesia Tahun 2017. Jakarta: Kementerian Kesehatan Republik Indonesia, 2018.

[4] Orjingene, O., \& Morgan, J. Effectiveness of Community Based Interventions in Reducing Maternal Mortality in SubSaharan Africa; A Systematic Review, 2020.

[5] Aryawati, W. Pengembangan Model Pencegahan Resiko Tinggi Kehamilan dan Persalinan Yang Terencana dan Antisipatif (Regita). Jurnal Kebijakan Kesehatan Indonesia, 86-93, 2016.

[6] Kabakyenga, J. K., et.al. Knowledge of Obstetric Danger signs And Birth Preparedness Practices Among Women in Rural Urganda. Reproductive Health , 110, 2011.

[7] Teng, S. P., et al. Knowledge of Pregnancy Danger Signs and Associated Factors Among Malaysian Mothers. British Journal of Midwifery, 800-808, 2015.

[8] Hailu, M., Gebremariam, A., \& Alemseged, F. Knowledge About Obstetric Danger Signs Among Pregnant women In Aleta District, Sidama Zone, Southern Ethiopia. Ethiop J. Health Sci, 25-31, 2010.

[9] World Health Organization. Counseling for Maternal and Newborn Health Care: A Handbook for Building Skills. Geneva: World Health Organization, 2013.

[10] Mourtada, R., Bottomley, C., Houben, F., Bashour, H., M., O., \& Campbell, R. A mixed methods analysis of Factors Affecting Antenatal Care Content; A Syrian Case Study. Plos one, 1-24, [2019]

[11] Assaf, S. (2018). Counseling and Knowledge of Danger Signs of Pregnancy Complications in Haiti, Malawi, and Senegal. Maternal and Child Health Journal, 1659-1667.

[12]Mwilike, B.,et al. Knowledge of Danger Signs During Pregnancy and Subsequent Healthcare Seeking Actions Among Women in Urban Tanzania; A CrossSectional Study. BMC Pregnancy and Chilbirth , 1-8, 2018.

[13] Mbalinda, S. N., Nakimuli, A., Kakaire, O., Osinde, M. O., Kakande, N., \& Kaye, D. K. Does knowledge of danger signs of pregnancy predict birth preparedness? A critique of the evidence from women admitted with pregnancy Complication. Health Research Police and Systems, 1-7, (2014).

[14] Al-Ateeq, M. A., \& Al-Rusaiess, A. A. (2020). Health Education During Antenatal Care; The Need for More. International Journal of Women's Health, 239-242.

[15] Salsabila, Q. N., Utami, A., \& Nugraheni, A. (2018). Efektivitas Edukasi Kesehatan (Ceramah dan SMS Gateway) Terhadap Pengetahuan Deteksi Dini 
Kehamilan Resiko Tinggi Pada Ibu

Hamil. Jurnal Kedokteran Diponegoro, 599-614. 